\title{
Measurement of Molding Sand Elasticity
}

\author{
Katarzyna Major-Gabryśa ${ }^{*}$, Aleksandra Grabarczyk ${ }^{a}$, Stanisław Marian Dobosz ${ }^{\mathrm{a}}$, Jarosław Jakubskía, \\ Jan Morek ${ }^{b}$, Jaroslav Beňo
}

${ }^{a}$ AGH University of Science and Technology, Faculty of Foundry Engineering, Department of Molding Materials, Mold Technology, and Cast Non-Ferrous Metals, Reymonta 23, 30-059 Krakow, Poland

${ }^{\mathrm{b}}$ MULTISERW-Morek Company, Marcyporęba 36, 34-114 Brzeźnica, Poland

'VŠB - Technical University of Ostrava, Faculty of Metallurgy and Material Engineering, Department of Metallurgy and Foundry Engineering, Ostrava, Czech Republic

*e-mail:kmg@agh.edu.pl

Received: 13 March 2018/Accepted: 27 April 2018/Published online: 26 June 2018

This article is published with open access at AGH University of Science and Technology Press

\begin{abstract}
The progressive mechanization and automation of industrial equipment is the driving force of progress, not only in the field of production but also in the measuring and control equipment. In mold production, the automation of processes such as forming molds and cores along with their assembly has led to increases in serial production, reductions in defects, and the shortening of molding times, among others. Thanks to automation in mold and core departments and the use of all sorts of manipulators, mold production in foundries has gained momentum.

Unfortunately, in addition to the mentioned advantages, there are also new challenges as to the quality and properties of the molding and core sands used in highly automated foundries.This article presents recent research on molding sand elasticity. The topic was introduced as an attempt to answer the new needs of highly mechanized foundries.

The article discusses a new method of measuring the resistance of molding materials to undergoing mechanical deformation (molding sand elasticity), with an additional analysis of the bending strengths of the tested samples. Precise measurements, test sample preparation, and interpretation of the received results are presented in the article.
\end{abstract}

\section{Keywords:}

molding sands, mechanical deformation, elasticity, hot-distortion

\section{NEW CHALLENGES}

Cores and molds are subjected to a variety of mechanical and thermal factors at each stage of their production and use. There are various technological operations that involve many possible sources of damage to the molds and cores. Operations such as the removal of cores from core boxes, removal of patterns from molds, core and mold assembly, applying weights to molds, etc. can generate cracks in cores and molds that may later lead to defects in the castings (Figs. 1 and 2). This is true especially in highly mechanized foundries, where such operations are often performed by manipulators. The reason for this is the high brittleness of the cores and molds. Hence, modern technology is looking for molding mixtures with relatively high flexibility/elasticity. This mainly applies to core sands prepared with the addition of synthetic resins [1-4].

Both foundry molds and cores are subjected to many destructive factors during their execution and assembly. In order to not damage the cores and molds, the used molding sand must not be too brittle to be damaged; however, at the same time, it must retain its shape and stiffness.
When cured, the synthetic resins used in the preparation of molding and core sands can be classified into polymer groups. The polymeric materials sustain different proportions of both elastic deformation and elastic and plastic (permanent) deformation during handling. The shares of the deformations depend on many parameters; for example, strain rate, temperature, deformation range, and the type of bond formed in the polymer material [5-8].

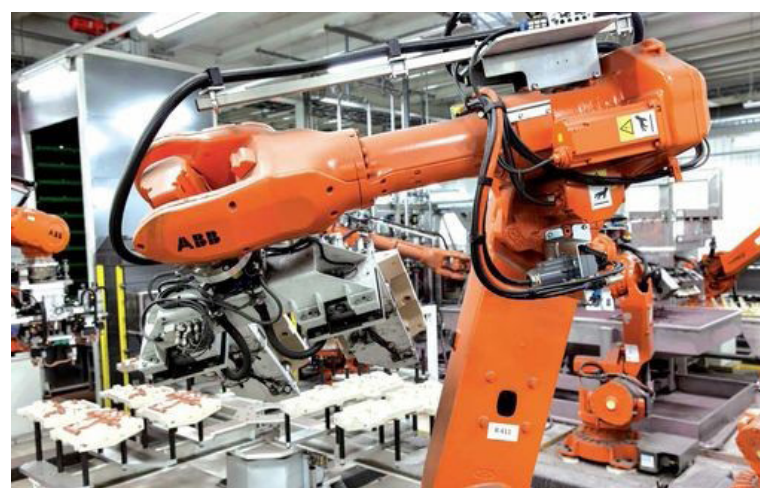

Fig. 1. Mechanized core and mold assembly [1] 


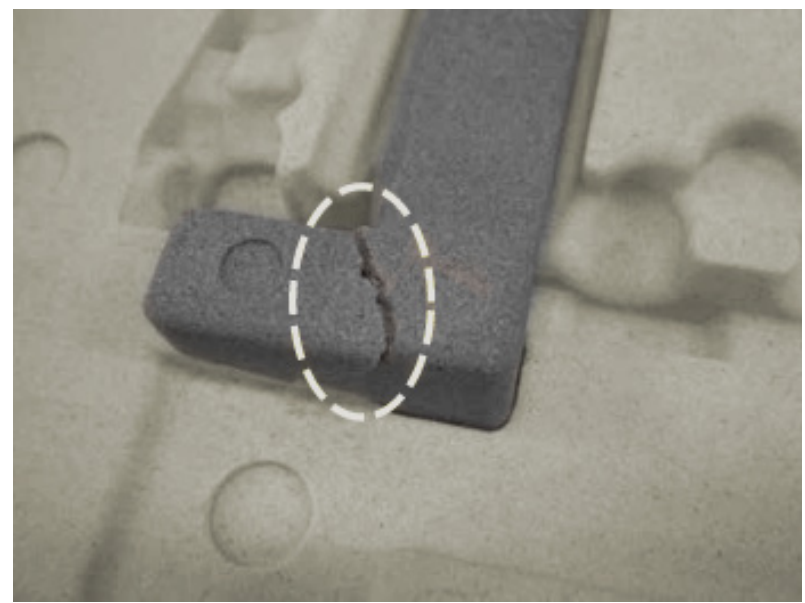

Fig. 2. Core fracture [2]

\section{RESEARCH METHODOLOGY}

The presented research was carried out on the new LRu-DMA measuring device from MULTISERW-Morek Company (Fig. 3). The research was carried out in the Department of Molding Materials, Mold Technology and Cast Non-Ferrous Metals at the Faculty of Foundry Engineering at AGH University of Science and Technology in Krakow $[9,10]$.

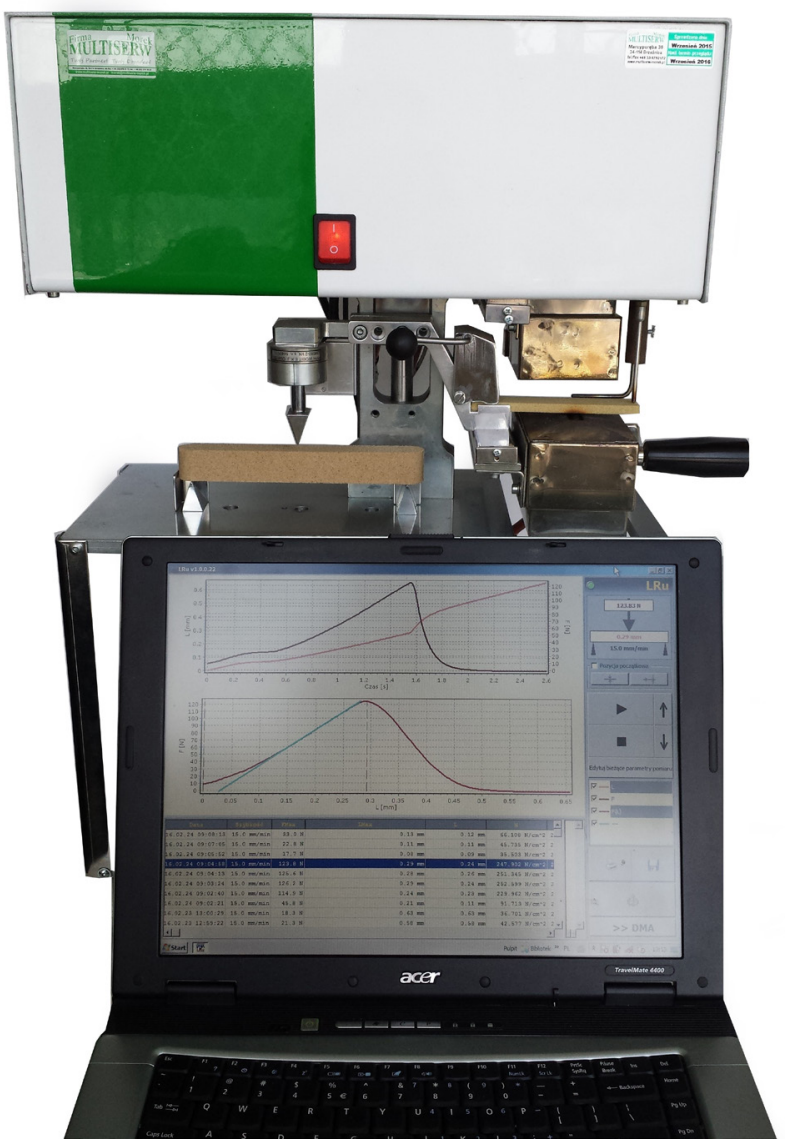

Fig. 3. LRu-DMA measuring device from MULTISERW-Morek Company
The presented device performs measurements in two modes:

- DMA - thermal deformation (hot distortion parameter),

- DE - measurement of elasticity (registration of deflection arrows with force registers).

Thanks to its modern and compact design as well as its use of new measuring systems, the device provides accurate results. The included software enables the export of results to popular office systems (Excel) and archives them in an independent database regardless of the device status.

\subsection{Molding sand mechanical deformation - elasticity}

In the study of polymer materials [7-12], elasticity is defined as a property that allows to make reversible shape changes under the influence of external forces. It should also be noted that, as a rule, we are not dealing with materials showing only one kind of deformation. In foundry molds, both spring and plastic deformation can occur in various shares. They may depend on different parameters; e.g., temperature or deformation speed.

The $D_{E}$-module, dedicated to mechanical deformation measurement, is used for estimating molding sand elasticity. It gathers information about the development of force over time with the simultaneous registration of the bend extend. This information is necessary for estimating the maximum bending force and maximum bending radius.

The elasticity measurement is based on the analysis of the deflection pattern of a standard longitudinal fitting during bending. The tooling (Fig. 4) allows us to perform measurements of the indentation force over time while recording its displacement. This allows the user to determine the bending strength $\left(R_{g}{ }^{u}\right)$ and deflection arrows [13]. The details concerning the elasticity measurement are described in earlier works [14].

The apparatus allows us to perform measurements of the indentation force over time while recording the indenter displacement. This allows the user to determine the bending strength of the sample as well as the deflection arrows.

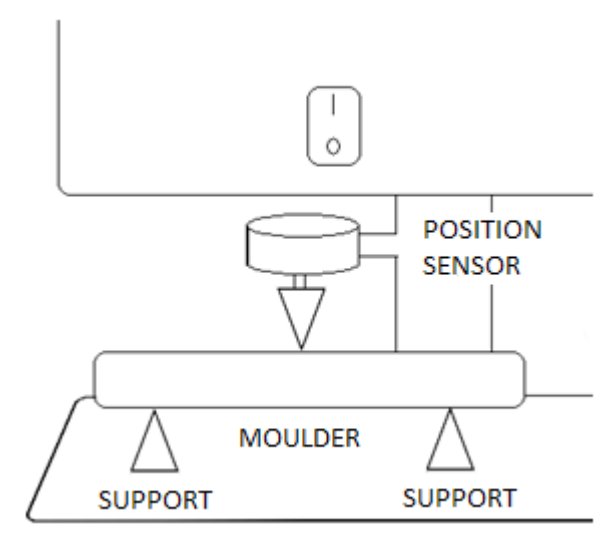

Fig. 4. LRu-DMA measuring device from MULTISERW-Morek Company - elasticity module 
The software provided by the manufacturer allows us to view the results in real time. In addition, it has the ability to display ready-made graphs showing the relationship between the applied force versus time as well as displacement and displacement as a function of time (Fig. 5).

By analyzing the graphs obtained by means of the device, it can be seen that the point of maximum force is applied at the moment of fracture under the indentation, while the part of the graph after that point is crossed is connected with the indenter retrieving back to the starting point of the measurement.

The program records the most important data such as time of measurement, indenter movement speed, maximum and momentary displacement and indenter force, sample size, and name.

The force-measuring range is 0 to $900 \mathrm{~N}$; in addition, it is possible to adjust the indenter's movement speed from 0 to $70 \mathrm{~mm} / \mathrm{min}$ in increments of $1 \mathrm{~mm}$. The built-in database allows us to determine the size of the fitting for each type of strength test (from $R_{g}{ }^{1}$ to $R_{g}{ }^{9}$ ), and it is possible to enter any dimension of the test piece.

There are two types of supports (20 mm and $38 \mathrm{~mm}$ ), which can be mounted in two spacings -10 and $15 \mathrm{~cm}$.
Thanks to this, the measurement capabilities of the device increase significantly.

The bending strength tests were carried out on standard longitudinal samples after $24 \mathrm{~h}$ of curing [13].

\subsection{Molding sand thermal deformation - hot distortion parameter}

The hot distortion parameter tests were carried out on numerous devices [13, 15-20]. In this research, a new approach to this measurement was used. The measurements of the thermal deformation of the molding sands were carried out on rectangular samples measuring $114 \times 25.4 \times$ $6.3 \mathrm{~mm}$ [13].

One of the ends of the fitting is fixed in the jaws of the device (Fig. 6), while the tilt sensor rests on the opposite (free) end of the sample. In addition, a temperature sensor is provided parallel to the fitting to increase the accuracy of the temperature measurement [13].

The heating system of the device allows the heating temperature to be adjusted independently for the upper and lower heating elements (which are $2 \times 400 \mathrm{~W}$ ceramic heaters, each with an independent built-in thermocouple).

a)

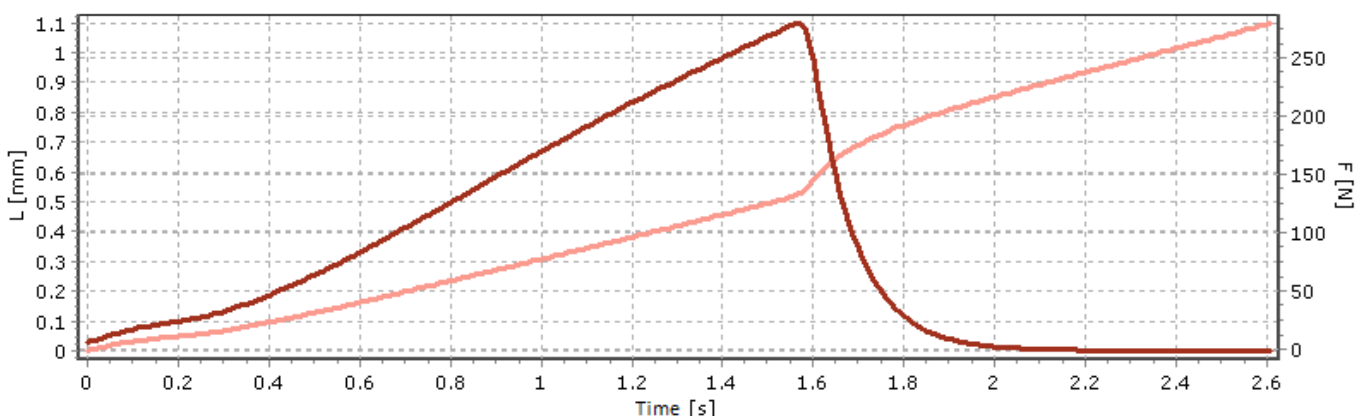

b)

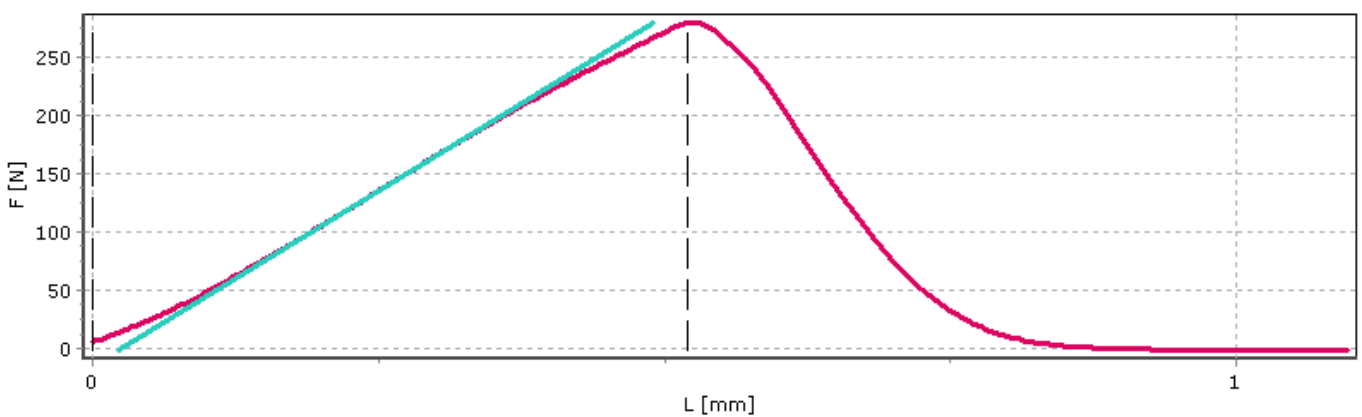

Fig. 5. Elasticity curves: a) deformation $L$ (brown curve) and applied force $F$ (orange curve) as a function of time; b) applied force $F$ as a function of deformation $L$ (red curve), deflection arrow (blue curve)

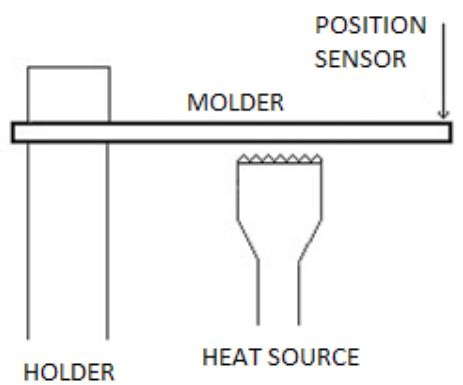

Fig. 6. LRu-DMA measuring device from MULTISERW-Morek Company - hot distortion module 
The device also allows the heating power to be controlled from 0 to $100 \%$ of maximum power (with increments of 1\%). The heating temperature ranges from room temperature to $900^{\circ} \mathrm{C}$ and can be set at $1^{\circ} \mathrm{C}$ increments, while the maximum deformation can range up to $10 \mathrm{~mm}$. In addition, metal overlays can be used to limit the heat emission field.

There is also the possibility of heating the upper and/or lower heating element to a set temperature (power \%) and placing it over and/or under the fitting. This gives us the opportunity to analyze changes in molding sand deformation, both in the case of the sudden exposure of the molding mixture to high temperatures (contact with the liquid alloy) and slow heating (heat radiation from the surface of the liquid metal) [21].

\section{OWN RESEARCH}

The following article focuses on the deformation of molding samples under pressure of force. The influence of the type of binding agent on the elasticity as well as the morphology of the crack surface are also taken into account. Considering the differences that occur between the different molding technologies, the type of bond destruction can play a leading role in molding sand deformation (among other properties) [22-25].

The presented results are a continuation of the authors' ongoing research described in detail in previous works [26-30].

The research was carried out in the laboratory of the Department of Molding Materials, Mold Technology, and Cast Non-Ferrous Metals at the Faculty of Foundry Engineering at AGH.

Both organic and inorganic binders were chosen for the study. They can be characterized by different mechanisms of destruction [27, 28]. Organic bonded molding sands can be characterized by adhesive destruction, while inorganic molding sands feature cohesive destruction [31]. The mechanisms of the destruction of these molding sands were studied in detail in previous works [32, 33].

As author Stanisław Dobosz [32, 33] points out in his thesis, the destruction of inorganic molding sands runs through the binder. This means that the adhesion forces between the binder and the grain surface are greater than the cohesion forces, which promotes breakage at the weakest place inside the binder layer (Fig. 7).

All of the molding sands that were chosen for this research were prepared according to the resin/binder manufacturer instructions using standard compositions (Tab. 1). Four representative molding mixtures that are widely used in the foundry industry were chosen for the research [21].

The following resins/binders were used:

- sands manufactured in cold-box technology - GASHARZ 6966 and AKTI-VATOR 7624 [34],

- self-hardening molding sands with furfuryl resin - XA-20 resin and 100T hardener [34],

- alkyd molding sands - SL2002 resin and KL1 catalyzer [35],

- inorganic molding sands - 145 hydrated sodium silicate and Flodur3 [14, 21, 35].

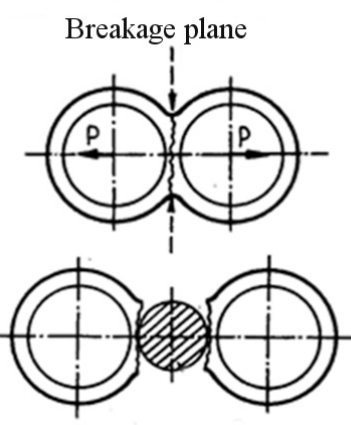

Cohesive breakage

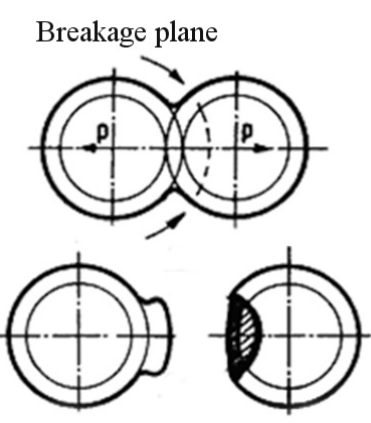

Adhesive breakage
Fig. 7. Cohesive and adhesive breakage [32]

Table 1

Tested molding sand composition [21]

\begin{tabular}{|c|c|c|c|}
\hline Name & Matrix & $\begin{array}{c}\text { Binder/resin, } \\
\text { p.p.w. }\end{array}$ & $\begin{array}{l}\text { Hardener, } \\
\text { p.p.w. }\end{array}$ \\
\hline $\begin{array}{l}\text { cold-box } \\
\text { technology }\end{array}$ & & 0.80 & 0.80 \\
\hline furfuryl resin & & 1.10 & 0.50 \\
\hline $\begin{array}{l}\text { alkyd resin } \\
\text { technology }\end{array}$ & & 1.00 & 0.25 \\
\hline ester technology & & 3.00 & 0.30 \\
\hline
\end{tabular}

Quartz sand was used in all of the conducted tests. According to Polish standard PN-85/H-11001, it classifies the tested sand as medium. In the studied matrix, the value of the main fraction is $84 \%$, which determines the sand as homogeneous.

The samples prepared with the use of hydrated sodium silicate (ester technology), furfuryl resin, and alkyd resin were prepared according to the binder producers' instructions using a laboratory mixer with a 4-kg capacity and compacted using an LUZ-1 laboratory vibration device. The molding sand used for the samples for cold-box technology was prepared in the same laboratory mixer but was not followed with compaction. The sand was placed in the MULTISERW-Morek Company Universal Core Shooter. The shooting parameters were set as follows: pressure - $0.5 \mathrm{MPa}$; time $-2 \mathrm{~s}$; amount of amine $-2.47 \mathrm{ml} / 1 \mathrm{~kg}$ of molding sand.

The density of the samples oscillated from $1.48 \mathrm{~g} / \mathrm{cm}^{3}$ to $1.63 \mathrm{~g} / \mathrm{cm}^{3}$. The sample population varied. For each graph a minimum of three samples that did not differ more than $10 \%$ in terms of the obtained results, was taken into account. 
The obtained results are illustrated in Figures 8-10.

Test samples showed analogical behavior in the bending strength test (Fig. 8) as they did in the elasticity tests (Fig. 9).

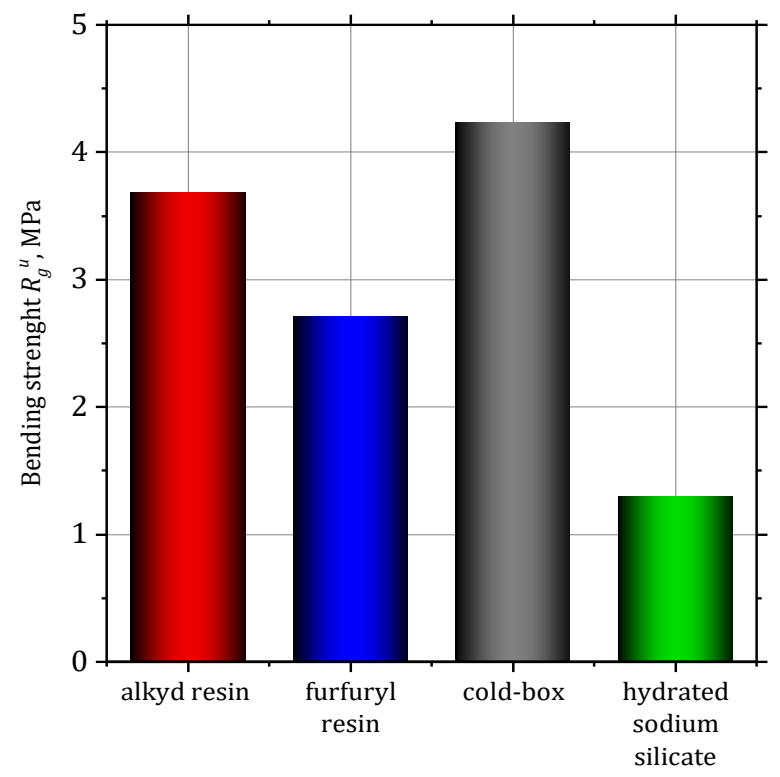

Fig. 8. Bending strength of tested molding sands

The highest results were achieved for the molding sands prepared in the cold-box technology, reaching 4.23 MPa. This was $69 \%$ more than for the molding sands with hydrated sodium silicate (which achieved the lowest value of $1.30 \mathrm{MPa}$ ). The molding sand with furfuryl resin reached a bending strength result of $2.71 \mathrm{MPa}$, and the molding sand with the alkyd resin reached $3.68 \mathrm{MPa}$ (which is, accordingly, 36\% and 13\% lower than the obtained maximum).

The results of the elasticity measurements give two types of information: the first being the maximum load $(F[\mathrm{~N}])$ that a sample can withstand, which is analogical to a sample's bending strength $\left(R_{g}{ }^{u}[\mathrm{MPa}]\right)$ and maximum deformation $\left(D_{E}[\mathrm{~mm}]\right)$, and the other is related to the deformation of different samples under a set force value (relating to the way the automated core assembly is realized).

The obtained curves (Fig. 9) visualize a few stages of the elasticity test. First, we can observe a nearly linear propagation of the deformation with increasing force. Second, we can observe a bend in the curve, which is the moment of sample breakage. The short growth of the curve after the maximal strength that the sample can withstand is not taken into the analysis - it is correlated with the eversion of the indenter.

As can be seen in Figure 9, the molding sand with hydrated sodium silicate as the binder achieved both the lowest deformation $(0.21 \mathrm{~mm})$ and load resistance $(64 \mathrm{~N})$. The molding sand bonded with the furfuryl resin obtained a value of $0.25 \mathrm{~mm}$ deformation and withstood $146 \mathrm{~N}$ of force. The molding sands bonded with the alkyd resin achieved the result of $0.36 \mathrm{~mm}$ in the bend under a force of $181 \mathrm{~N}$. The highest obtained results both in deformation and load size were achieved in the molding sand prepared in the cold-box technology; deformation reached $0.55 \mathrm{~mm}$ under a force of $214 \mathrm{~N}$ just before the sample's destruction. The resulting deformation was nearly $62 \%$ greater than the molding sands with the hydrated sodium silicate (under more than 70\%-greater force).

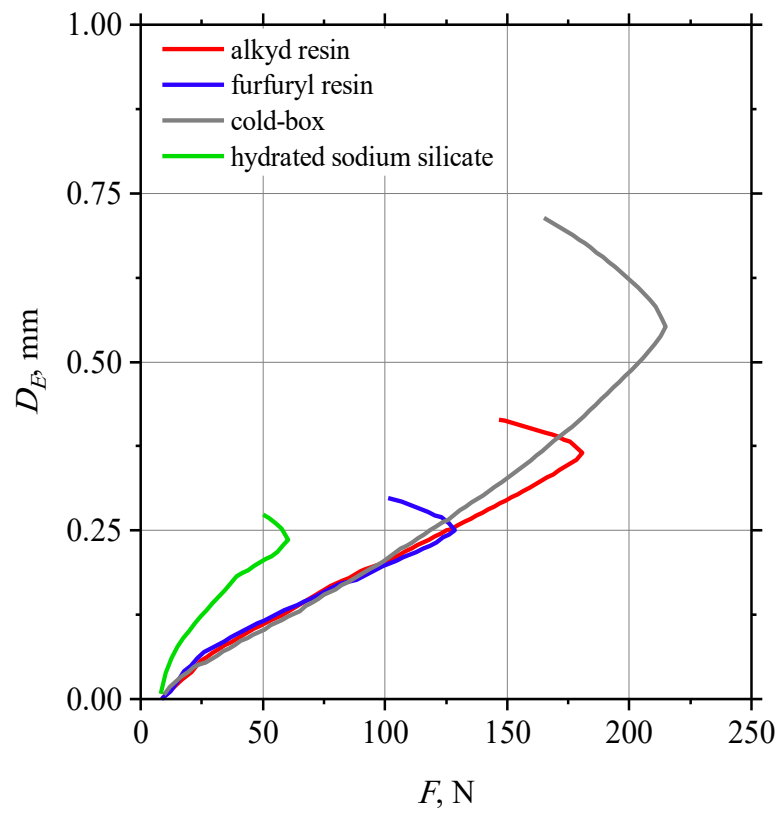

Fig. 9. Elasticity of tested molding sands

Based on both elasticity and bending strength, it can be easily deduced that the greater the bending strength and overall strength resistance of the molding sand, the greater deformation the sand will undergo and withstand. However, this is only an analysis of the final outcome after destruction of the samples. What has to be pointed out is the deformation of the samples made from different molding sands under the same force.

If, for example, the impact of a force of $50 \mathrm{~N}$ on the deformation of a chosen molding sand would be taken into account, it can be seen that the highest deformation under this pressure is $0.19 \mathrm{~mm}$ for molding sands with the hydrated sodium silicate. At the same time, the molding sands with organic-type binders reaches very similar results of $0.11 \mathrm{~mm}$ under the same force of $50 \mathrm{~N}$, which is roughly half of what was obtained for the inorganic sand mixture [21].

The last stage of the research presented in this paper is the measurement of molding sand thermal deformation by determining the hot distortion parameter. Thanks to the latest alterations in the measuring equipment, it was possible to mount the sample and pre-heat the equipment without interfering with the sample. This increased the repeatability of the measurement. The lower (bottom) heating plate in the measuring device was pre-heated to $900^{\circ} \mathrm{C}$ and then placed below the sample. Both the time and temperature were measured on the sample level. 
The results are illustrated in Figure 10.

a)

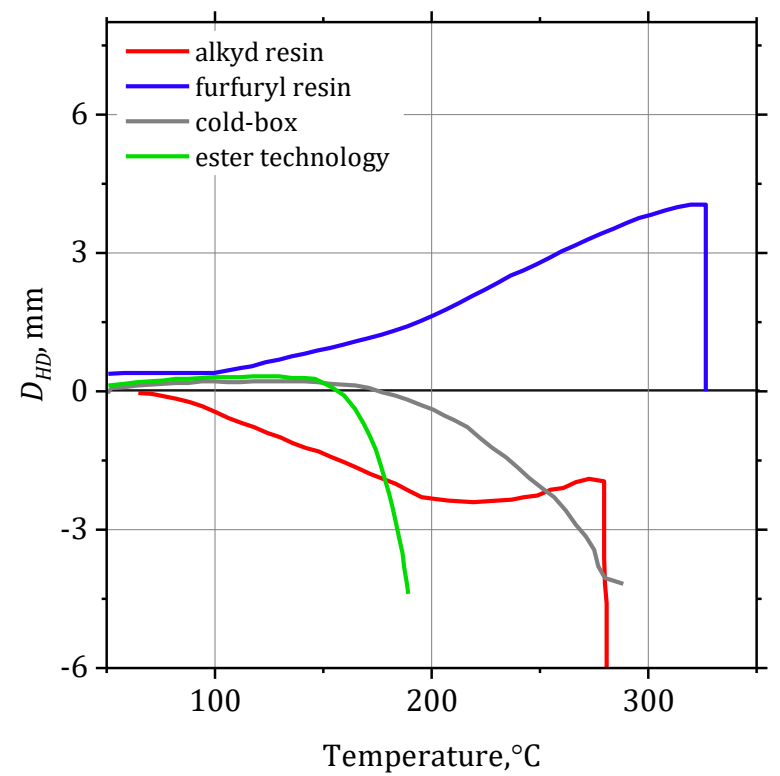

b)

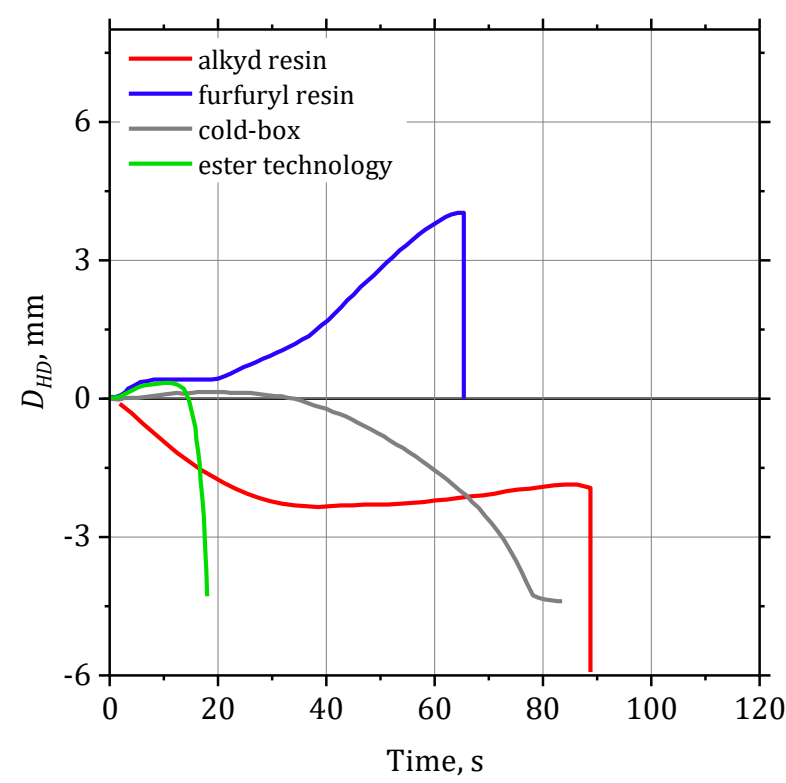

Fig. 10. Thermal deformation of tested molding sands: a) deformation $\mathrm{D}_{\mathrm{HD}}$ as a function of temperature; b) deformation $\mathrm{D}_{\mathrm{HD}}$ as a function of time

The thermal deformation of the molding sand with the furfuryl resin has a typical pattern, with an intense deformation of the sample (exceeding $4 \mathrm{~mm}$ ) and its sudden destruction at a temperature of about $325^{\circ} \mathrm{C}$ - the deformation was in the opposite direction to the heat source. The deformation of the molding sand with the alkyd resin exceeds approx. $1.5 \mathrm{~mm}$, and the sample collapses at $266^{\circ} \mathrm{C}$ - the direction of the deformation was headed towards the heat source. The thermal deformation tests (hot distortion parameter) showed that the molding sands with the hydrated sodium silicate and those prepared in the cold-box technology are characterized by better heat stability than the molding sands with the furfuryl and alkyd resins. Both of the tested mixtures exhibit almost no thermal deformation at a temperature range of 0 - approx. $160^{\circ} \mathrm{C}$. After crossing the above-mentioned temperature, the samples are subjected to mild deformation until they are damaged. The molding sand prepared in the cold-box technology is characterized by the longer time needed for the sample's destruction (about 55 seconds), while the sample made from the molding sand with the sodium silicate begins to degenerate after about 15 seconds. This can be advantageous in terms of the time of contact of the molding/core sand to elevated temperatures during and after the pouring process.

\section{CONCLUSIONS}

Our own research presented in the paper showed the following:

- There are various differences in the behavior of molding sands exposed to bending forces depending on the type of binder used.

- The presented research proves that the change of the used binder and technology influences the level of molding sand deformation at ambient temperatures.

- The conducted research shows that molding sands with inorganic binders that tend to have cohesive type of breakage, achieve lower values in both deformation at ambient temperatures and bending strength when compared to organic binders with the adhesive type of breakage.

- Molding sands with hydrated sodium silicate and molding sands prepared in the cold-box technology are characterized by better heat stability than molding sands with furfuryl and alkyd resins. The longer time needed for the sample destruction achieved for the molding sand prepared in the cold-box technology can be advantageous in terms of the time of contact of the molding/core sand to elevated temperatures during the pouring process.

The presented article shows only a fragment of the broader research on this topic. The need for seeking new testing methods is clearly visible, and the parameter can prove to be a valuable asset in choosing the optimal molding sands for highly mechanized foundries.

\section{Acknowledgements}

The research was funded as a part of AGH Research Project no. 11.11.170.318.

\section{REFERENCES}

[1] Gröning P., Schreckenberg S. \& Jenrich K. (2015). Herstellung von hochkomplexen Zylinderkurbelgehäusen (part 1). Giesserei, 102(01), 42-47.

[2] Gröning P., Schreckenberg S. \& Jenrich K. (2015). Herstellung von hochkomplexen Zylinderkurbelgehäusen (part 2). Giesserei, 102(01), 48-53.

[3] Gröning P. \& Serghini A. (2012). New cold-box systems and additives for serial production of castings. III Conference „Moulding and core materials - theory and practice”, 20-22 May. Zakopane, Hüttenes-Albertus Poland. 
[4] Stauder B.J., Kerber H. \& Schumacher P. (2016). Foundry sand core property assessment by 3-point bending test evaluation. Journal of Materials Processing Technology, 237, 188-196.

[5] Galina H. (1998). Fizykochemia polimerów. Rzeszów: Politechnika Rzeszowska.

[6] Przygocki W. (2001). Fizyka polimerów. Warszawa: Polskie Wydawnictwo Naukowe.

[7] Sperling L.H. (1992). Introduction to physical polymer science. New York: Wiley \& Sons.

[8] Riande E., Díaz-Calleja R., Prolongo M.G., Masegosa R.M. \& Salom K. (1999). Polymer Viscoelasticity: Stress and Strain in Practice. New York: CRC Press.

[9] Zych J. (2013). Bench Life (Work Time) of Moulding and Core Sands with Chemical Binders - a New, Ultrasound Investigation Method. Archives of Foundry Engineering, 13(4), 117-122. DOI 10.2478/afe-2013-0094.

[10] Zych J. (2007). Behaviour of moulding sands with hydrophilic binders in dry air. Archives of Foundry Engineering, 7(4), 189-192.

[11] Głuch S. (2016). The influence of hardening parameters on deformation of cores during resistance measurement on chosen moulding sands in cold-box technology. Engineering thesis. Kraków: Akademia Górniczo-Hutnicza.

[12] Hutera B., Lewandowski J.L. \& Smyksy K. (1999). Wpływ temperatury na właściwości wybranych mas formierskich. Archives of Foundry Engineering, 6(20), 71-76.

[13] Grabarczyk A., Dobosz S.M., Major-Gabryś K., Jakubski J. \& Morek J. (2015). Elastyczność - nowe kryterium oceny jakości mas formierskich. Archives of Foundry Engineering, 15(4), 39-42.

[14] Lewandowski J.L. (1997). Tworzywa na formy odlewnicze. Kraków: Wydawnictwo AKAPIT.

[15] Morgan D. \& Fashman E.W. (1975). The BCIRA Hot Distortion tester for quality in production of chemically bonded sands. AFS Transaction, 91, 73-80.

[16] Ramrattan S., Vellanki S., Jideaku I. \& Huang C. (1997). Thermal distortion in process control of chemically-bonded sands. AFS Transaction, 125, 161-165.

[17] Rodriguez J., Keil M., Ramrattan S. \& Krysiak M.B. (1989). Industry and academia collaboration for a thermal distortion tester for sand-binder systems. 1998 Annual Conference, 28 June 1989, Seattle, Washington, USA.

[18] Ignaszak Z. \& Popielarski P. (2009). Heat Transfer During Hot Distortion Test of Ceramic Porous Material Bonded by Various Resins. Defect and Diffusion Forum, 283-286, 382-387.

[19] Ignaszak Z. (2008). Chosen aspects of thermo-mechanical phenomena in resin bonded sands by use of Hot Distortion tests. Archives of Foundry Engineering, 8(1), 137-142.
[20] Giese S.R., Roorda S.C. \& Patterson M.A. (2009). Thermal Analysis of Phenolic Urethane Binder and Correlated Properties. AFS Transactions, 102, 355-366.

[21] Grabarczyk A., Dobosz S.M., Kusiński J. \& Major-Gabryś K (2018). The tendency of moulding sands to generate core cracks. Archives of Foundry Engineering, 18(1), 157-161.

[22] Hutera B. (2004). Wpływ wybranych parametrów fizykochemicznych na wytrzymałość mas formierskich. Archiwum Technologii Maszyn i Automatyzacji, 24(1), 115-122.

[23] Löchte K. (1998). Working with the Cold Box Process in the Coremaking Department of a Foundry. Hüttenes-Albertus Chemische Werke GmbH, July 1998, 1-21.

[24] Baliński A. (2017). Effect of the way of modification of hydrated sodium silicate on the effectiveness of the changes in the residual strength of a moulding sand. Transactions of Foundry Research Institute, 57(3), 161-168.

[25] Psimenos A.Ch. (2008). Core and molding production with nobake binder systems. Giesserei Praxis, 4, 111-119.

[26] Dobosz S.M., Grabarczyk A., Major-Gabryś K. \& Bolibruchova D. (2017). Elasticity of cores manufactured in cold box technology. Archives of Metallurgy and Materials, 62(1), 351-354.

[27] Dobosz S.M., Grabarczyk A., Major-Gabryś K. \& Morek J. (2016). Quality assessment of the moulding mixtures from the elasticity point of view. Technológ, 8(2), 19-23.

[28] Major-Gabryś K. (2015). Biodegradable materials as binders for IV $^{\text {th }}$ generation moulding sands. China Foundry, 12(5), 375-381.

[29] Huang R., Gao H., Tang Y. \& Liu Q. (2011). Curing mechanism of furan resin modified with different agents and their thermal strength. China Foundry, 8(2), 161-165.

[30] Mullier M.A., Seville J.P.K. \& Adams M.J. (1987). A fracture mechanics approach to the breakage of particle agglomerates. Chemical Engineering Science, 42(4), 667-677.

[31] Subero J. \& Ghadiri M. (2001). Breakage patterns of agglomerates. Powder Technology, 120(3), 232-243.

[32] Dobosz S.M. (1990). Aktywacja cieplna piasków kwarcowych. Kraków: Wydawnictwo AGH.

[33] Dobosz S.M. (2006). Woda w masach formierskich. Rozprawa habilitacyjna. Zeszyty Naukowe AGH "Metalurgia i Odlewnictwo" (134), Kraków.

[34] Hüteness-Albertus Polska (producers catalouge).

[35] PrecOdlew - producers website. Retrieved January 24, 2018, from http://odlew.com.pl/zywice-i-utwardzacze-odlewnicze 